\title{
Values of Upper Secondary Learners and Role of Mathematics in their Development
}

\author{
Vanda ARAMAVIČIŪTĖ \\ Department of Educational Science, Vilnius University \\ Universiteto str. 9/1, LT-01513 Vilnius, Lithuania \\ e-mail:aramaviciute@yahoo.co.uk
}

Received: August 2006

\begin{abstract}
The article aims at raising the problem of culture in the context of globalisation, at characterising influence of globalisation and globalisation culture on human values and relation as expression of their spiritual world. In this context, a question of intermediary communication influence on individual's spiritual becoming is also raised. On the basis of own research data, the author defines peculiarities of internalisation level of upper secondary learners' spiritual values, observed in 1998, 2001 and 2005. On the basis of comparison, information regarding cognitive, emotional and behaviour level of internalisation and tendencies of its changes are analysed. The possibilities of teaching process, as a relevant factor of education, internalising values are concretised and the role of mathematics in this process is defined.
\end{abstract}

Key words: globalisation, culture, values internalisation, teaching process, mathematics.

\section{Introduction}

Globalisation is one of the strongest tendencies of modern world development. Through strengthening of individual's relations with surrounding world, globalisation opens up new perspectives. On the other hand, globalisation may impair person's links with local communities and separate individuals. On the basis of sociologist Giddens' (2000) point of view, globalisation is a dual process which comprises what is happening "not here" and "here" as well as global or purely local, personal changes that may negatively affect person's national and spiritual identity.

On the other hand, though a multipartite process of globalisation comprises a lot of spheres, culture plays a particular role. Researchers in globalisation (Giddens (2000), Džežulskis-Dienys (2004), Thompson (1990), Tomlinson (2000), Kuzmickas (2003), Morkūnienè (2003), etc) emphasise that powerful globalisation processes cannot be appropriately perceived without relation to culture. Identifying culture as a globalisation dimension, they make an attempt to determine an influence of globalisation on culture as well as an impact of a constantly changing culture on people's life.

Though culture is a multidimensional phenomenon, determining it, globalisation theoreticians are intended to bear in mind activities that give sense to people's life. Culture is perceived as a relevant sphere of purport that comprises all the activities of a person 
and provides important personal meanings. It is worth mentioning that this point of view is supported by culturologists, who emphasise manners of person's activities and his/her lifestyles or accentuate a notional-value based feature of culture or, finally, perceive culture as education, improvement of something and development of certain qualities. According to culturologist Andrijauskas (2000), a modern perception of Western culture is often associated with person's spiritual-moral perfection that forms an inseparable part of aggregated spiritual values.

Globalisation, which is based on a complex idea of interlinking, affects purportrelated sphere of person's life. Therefore, it is important to identify how it changes the context of meaning construction: how person's relations with local community and separate people are affected, what influence on values that substantiate these relations can be observed, how internalisation (adoption) of value occurs, what changes in identity are observed, etc. It is important to remember that globalisation, estranging culture from a particular location, expands extent of globalised culture. This process, limiting a variety of cultural systems, enhances threat of national culture extinction and entrenchment of cosmopolitism. In the context of changes in purport, the problem of both human relations and values supporting them arises.

Changes in human relations are also conditioned by forms of mediating communication carried out through information and communication technologies. Though modern life cannot be imagined without such communication, scientific literature has started to analyse its possible negative effects. According to philosopher Kuzmickas (2003, p. 35 ), information and communication technologies 'change not only manner of communication but also personality's spiritual world', for relations established through various technologies may turn into second rate contacts that cannot satisfy needs of true nearness and intimacy. Human relations are also affected by other global tendencies, especially by an increasing emancipation of individuals or a constantly strengthening liberation from some traditional subjections (communal, family, civic, confessional), which may develop into individualism prompting alienation of human relations and indifference to superlative values.

In fact, it is important to perceive the influence of culture itself on globalisation development since creation of purport conditions not only consequences of separate individuals' activities but also those of community activities. Tomlinson (2002) points out, that cultural marking and interpretation constantly direct people towards certain actions that may have global effects.

Undoubtedly, all this raises a big number of educational problems related to adequate evaluation and regulation of globalisation influence on the growing generation. This problem is discussed word-wide in works of educators who focus on issues related to value cognition and education of learners. In the context of these questions the role of teaching process is emphasised and its optimal employment for development of school learners' value principles is highlighted. All this necessitates a deeper analysis of educational potential of separate subjects. Social and humanitarian sciences are frequently considered to have the highest potential but real possibilities of subjects of natural science and mathematics cycle are also emphasised. 
Having taken into account the above mentioned, changes in internalisation of upper secondary (17-18 years old) learners' spiritual values and pedagogical preconditions for their regulation have been chosen as the object of the pilot research. The goal of the research: on the basis of the long-term research results, to identify tendencies of upper secondary learners' spiritual values internalisation that occurs in the context of contemporary globalisation.

The methods of the research: M. Rokeach methodology of value orientations, descriptors of attitudes and behaviour, tests of emotional experiences and unfinished sentences, statistical methods (calculation of absolute and percentage frequencies, factor and correlation analysis, chi-squared test). SPSS (Statistical Package for Social Science), 10.0 version of software was applied processing the research data.

The research was organised in three stages. During the first stage (1998) 220 upper secondary school learners were surveyed by random sampling, the sample in the second stage (2001) included 257 learners and 127 respondents participated in the third stage of the research. The survey was conducted in schools of Vilnius, Klaipeda and Šilalè.

This article aims at describing peculiarities of internalisation level of upper secondary learners' values, describing influence of teaching on values internalisation and actualising potential of mathematics in the process.

\section{Peculiarities of Internalisation of Upper Secondary Learners' Values}

Internalisation of values occurs when values become an internal content of a person, motivating and regulating his/her behaviour and activity. Making values an integral part of internal personality self-being or internal motives is the keystone of internalisation. Having transformed into motives, values start functioning in various forms that manifest cognitive, emotional and practical (behaviour) level of internalisation. Every level reflects internalisation process in different way: cognitive level demonstrates extent of perception of values essence, purport and its acknowledgment; emotional level expresses living through purport of values, which stimulates a wish to choose values and to resolve to base own life on them; behaviour level manifests format of practical implementation of values through concrete actions.

To form a clear view of cognitive level of values internalisation, first of all an attempt was made to reveal attitudes of upper secondary school learners to values. As an expression of cognitive level, attitude to values reflects cognitive-emotional relation with them. Positive (favourable) attitude is one of the key indicators of internalisation, reflecting functioning of values at personality level.

Research in attitudes of upper secondary learners to spiritual values took into consideration: 1) degree of acknowledgment of value importance; 2) character of substantiation of value importance. The methodology of $\mathrm{M}$. Rokeach to identify acknowledgment range of 18 terminal values (final, higher, values-goals) and 18 instrumental values (enabling to materialize the terminal ones) was applied. Attributing a certain range to a value, the learners recognized level of its importance and expressed own attitude to the value. Simultaneously, the level of changes in learners' attitudes to the above-mentioned values through eight years was identified. 
The received data of comparison showed that more than a half of the learners $(62.7 \%$ $54.1 \%$ ) in the survey of 1998 considered mature love and internal harmony as the key terminal values. In psychology and philosophy, the both values are named as broad value orientations that possess a clear-cut meaningfulness and determine the becoming of personality to greatest extent. Approximately the same number of learners (fewer, though) acknowledged wisdom, true friendship and happy family. 49.0\%-45.5\% emphasised a happy life, happiness and freedom, more than a third (35.4\%) pointed out self-respect as a relevant value. Actually, a bigger part of upper secondary learners were intended to positively evaluate the values that would enable them to achieve welfare and completeness of life (personal and that of other people).

Comparing the results with those of 2001, it can be stated that the upper secondary school learners' attitudes to the above mentioned values remained almost stable, except some fluctuations: there was a slight increase (7.6\%) in acknowledgment of wisdom $(x 2-$ $16.4, p 0.05)$, recognition of happiness also increased partially $(6.0 \%)$, evaluation of true freedom slightly decreased $(11.6 \%)$ as well as that of inner harmony $(5.8 \%)$. Certain changes in the scales of freedom, happy family and happy life were observed but the variations were not statistically significant.

The results of the research in 2005 confirmed an increasing negative attitude to true friendship (an increase of $8.1 \%$ in the proportion of the learners who do not consider this value to be important) and wisdom (9.6\%); however, a strengthening positive attitude to a happy family (the number of learners acknowledging in increased by $9.1 \%$ ), to happiness $(5.9 \%)$, partially to freedom and self-respects $(3.7 \%)$ was identified.

The analysis of the data revealed the least relevant terminal values in upper secondary learners' opinion (Fig. 1).

Thus, in 1998 values of low-acknowledgment included beauty, equality, escape or recovery from a difficult disease or escape from a difficult situation, national security (only one seventh or eighth considered them to be important). Similar to the value of

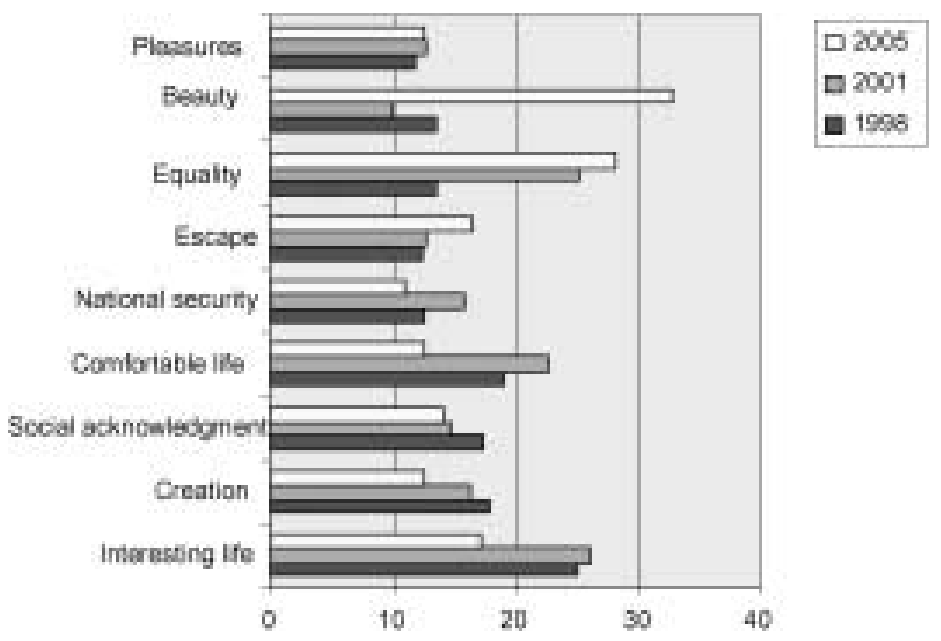

Fig. 1. The terminal values least acknowledged by senior school learners. 
pleasures, all those values were acknowledged only by few upper secondary learners. A slight difference was observed in evaluation of creation and social acknowledgment (only one sixth of the learners in the research attributed them to the class of important values; they took similar place to value of comparable life and a bit lower than that of interesting life). Consequently, freedom and independence of nation, peace and equality as well as creation were not very relevant and equalled to pleasures and comfortable life. Too low acknowledgment of such values may weaken learners' attitudes to self-development, to take care of welfare of others and to expand limits of direct and indirect hedonism.

The research of 2001 revealed only a more considerable increase (12.6\%) in evaluation of equality $(x 2-29.4, p 0.001)$ and a very slight rise $(3.1 \%)$ in that of national security. The results of 2005 showed that a positive attitude to national security has a tendency to go down (a fall of $4.9 \%$ in the number of senior learners who evaluated it as important). Similar tendencies were observed regarding acknowledgment of creation, interesting and comfortable life. On the other hand, a considerable upward tendency was observed in the learners' attitude to beauty (an increase of a quarter in number of respondents positively evaluating it).

In 1998 the most important instrumental value among upper secondary learners was responsibility (over half of the respondents acknowledged that). Important values comprised altruism, intelligence, education (less than $50 \%$ of the respondents), sensitivity and respectability. Less important values for the learners included forgiveness, independence and courage (more than one third of the respondents). Thus, the respondents prioritised moral values as the core of the goodness among which the learners inserted the gnostic values that are related to the truth.

The changes in the attitudes of the learners to such values, revealed in the research of 2001, can be named as fluctuations of opinions and concern changes in attitude to sophistication $(x 2-20.2, p 0.01)$, independence $(x 2-21.2, p 0.01)$, sensitivity $(x 2-$ 18.6, $p 0.05)$ and courage $(x 2-16.8, p 0.05)$ : acknowledgment of sophistication slightly increased $(8.3 \%)$ and as well as that of sensitivity and independence $(7.2 \%)$.

The research of 2005 showed that more respondents (10\%) than earlier highly evaluate responsibility that presupposes moral relations of people. Courage, as opposition to cowardice, gains a more favourable status (the number of the respondents who consider such values important rose by as much as $15.9 \%$ ). The positive attitude to forgiveness, as an important spiritual value, increased; whereas, a fall in evaluation of sophistication and intelligence, as gnostic values, that enable individuals to discover and cognise other spiritual values was observed.

Form the point of view of bringing up, it is important to identify such instrumental values that the upper secondary learners are tended not to acknowledge, since they may impede actualisation of the terminal values (Fig. 2).

It is obvious that in 1998, obedience was the least acknowledged value among senior school learners, most frequently perceived as depersonalised humiliation rather than an authentic presence of spiritual life or amiability towards others. The upper secondary students were not intended to rate dignity highly, though this value expresses not only own supremacy but also striving for high ambitions, possession of self-value and pursuance 


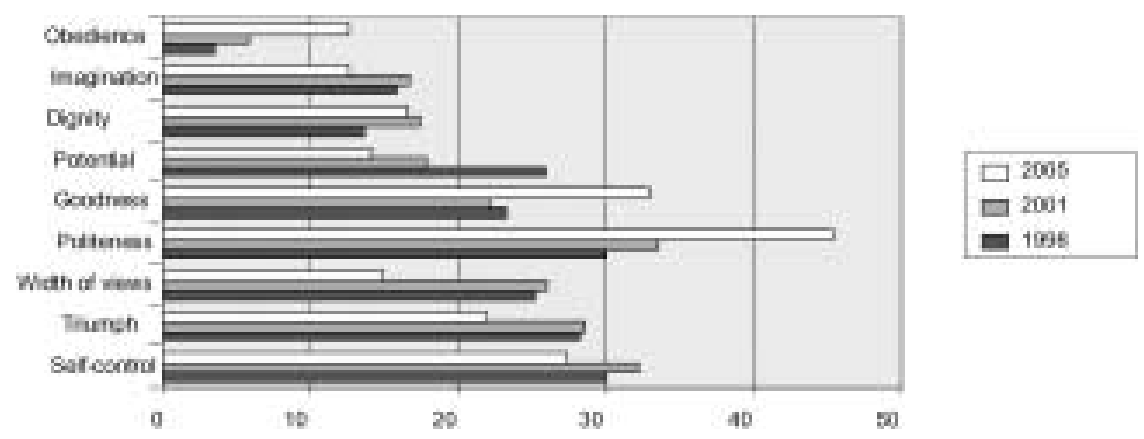

Fig. 2. The instrumental values least acknowledged by senior school learners.

of sublime principles. Insufficient value is attached to imagination, potential comprising mechanisms of creative and productive activity. However, more respondents (only a quarter, though) evaluated dignity and politeness. Width of views and self-control received similar evaluations. However, the results of correlation analysis showed that too little acknowledgment of such values may hinder retention of mature love, happiness, happy family, national security and to suppress a weak disposition to creation, to contract self-respect and social acknowledgment.

The results of the 2001 research revealed a slight (5.9\%) rise in the number of learners who attach more importance to politeness. Whereas the results of the research conducted in 2005 confirmed an increasing positive attitude not only to politeness (an increase of $12.2 \%$ in the number of the respondents ranging this value high), but also to dignity (10.8\%) and obedience (6.7\%). However, self-control, width of views, triumph and imagination gained lower evaluation. Thus, evocation of positive approach to such values among upper secondary school learners is a problem of importance of this age group.

Striving to identify how senior school learners perceive purport of terminal and instrumental values, the depth of perception of values purport was selected as the criterion for evaluation. The main factor deterring this perception is reference of the value purport not only to own welfare but also to that of other people or community.

The research results of all the stages showed a lower perception of the purport of terminal values compared to that of instrumental ones. On the other hand, in 2001 more respondents failed to perceive this purport than in 1998 ( $x 2-20.8, p 0.001)$ : the proportion of the respondents who related it to a higher level of personal welfare, which enables a person to become a more mature and harmonious personality amounted to $20 \%$. Therefore, the proportion of the learners attaching a hedonistic, pragmatic purport to terminal values gradually increased ("I'll be more pleased", "it will be easier for me", "it will be more convenient for me", etc) that leads to a lower level of personal welfare. The number of learners who tended to harmonisation of other person's and own spiritual welfare was low (less than 5\%). One tenth of the senior school learners failed to explain the purport of values.

The perception of purport of instrumental values of the respondents in 2001 was lower compared to that of upper secondary learners in 1998. This revealed a tendency that 
values are more and more often perceived as an instrument of hedonism and pragmatism rather than a source of own purposive assertion and that of others. The research results of 2005 allow for modification of this conclusion since they demonstrate return to the situation revealed by the research results of 1998 .

As it was mentioned before, the attitude to values is not only rational but also an emotional one. Emotions perform a wide range of functions such as evaluations, orientation or intermediation including motive of activity. Occupying various places in the structure of individual's motivation, they differently influence becoming of personality. Firstly, it is important what world objects or phenomena condition that, how relevant they are to a person and whether they meet his/her needs. Therefore, the experienced emotions gain different power of attraction and become desirable and pleasant, or on the contrary, unpleasant, undesirable and provoking negative images to an individual. From the point of view of psychologists, emotions providing the highest degree of satisfaction reflect emotional singleness of an individual or a particular attraction not to any but to particular emotions that are closely related to his/her certain needs. Therefore, investigating the emotional level of values internalisation, a positive attitude of the respondents to certain emotions was selected as a point of departure. This attitude is a dimension of emotional singleness.

The research results revealed that in 1998, the following emotions were the most pleasant and provided the highest satisfaction to upper secondary students: practical emotions (or success of work, good results), communicative emotions (communication with respected and loved people), romantic emotions (unknown location, environment) and hedonistic emotions (good physical self-feeling, tasty food, unrestricted environment). However altruistic emotions (doing good to close and dear people) that make up the core of moral feelings as well as gnostic emotions (cognition of new, wonderful and unusual facts of science) received a significantly lower evaluation compared to the hedonistic ones. The role of esthetical emotions (perception of nature and art as sources of beauty) was especially low with upper secondary learners. Thus, doing good to close people, nature, art and science provided few positive and pleasant emotions. Three years later (2001) practical and communicative emotions remained among the most pleasant. The number of learners who considered altruistic emotions to be more pleasant increased slightly $(10.6 \%)$, whereas the proportion of ones who perceived romantic emotions as a source of pleasure fell down (13.3\%).

The research results of 2005 revealed more positive changes: an increasing attraction of learners to gnostic (a rise of $15.7 \%$ in the proportion of respondents who see such emotions as a source of satisfaction and enthusiasm), practical (14.2\%), communicative (13.6\%) and altruistic (11.5\%) emotions that make up the core of spiritual experiences. A slight increase in senior learners' attraction to esthetical emotions (4.6\%) was also observed. It goes without saying that these emotions may facilitate internalisation of certain spiritual values together with person's personality maturity.

Practical personalisation of values demonstrates a higher level of internalisation than cognitive or emotional. Behaviour is considered to be the most real manifestation of values internalisation. Actually, it depends on the stability and value of the conducted actions. 
Evaluating behaviour of upper secondary learners by stability criterion, it was revealed that throughout approximately eight years almost two thirds of the learners of this age were more often successful in practical realisation of certain moral values such as faithfulness, responsibility, honesty, respect and sensitivity. On the other hand, the results of the researches of 2001 and 2005 demonstrated a big number of positive changes in behaviour: a more frequent exercise of duties, telling the truth, manifestation of self-respect and respect to others, concern about others, devotion to work, faith. However, certain negative changes were observed: less frequent experience of beauty, openness to novelty, self-expression of intellect, independence and tolerance. Slight fluctuations were identified that revealed lower level of practical implementation of creativity, tolerance and altruism. Thus, not only personalisation of esthetical and gnostic values but also that of moral values remains a topical social and pedagogical problem.

\section{Employment of Teaching Process for Values Development}

Pedagogical literature presents teaching process as one of the key factors in personality development. During this process, the learners not only gain certain science knowledge, skills and abilities but also form value principles, position, point of view, character, etc. Generalising it can be stated that teaching/learning processes comprise development of a person which aims at facilitating individual's identification and internalisation of highest values as the basis for dissemination and evolution of human nature as well as at the establishment of adequate relations with oneself and the world based on these values that stimulate an individual to act and behave according to them. Taking into consideration the research results of the author and other researchers (Martišauskienè, 2004; Ivanauskienè, 2002; Krakauskienè; Trinkūnienė; Žilinskaitè, 2004; etc.) regarding values and relations of contemporary school learners, the employment of the teaching process in development of value orientations and attitudes is becoming one of the key objectives in contemporary pedagogy. Striving for achievement of this objective, it is relevant for an educator:

1. To penetrate into the factors determining the educational effect of the teaching process: objective (teaching goals, content, organisation, relations) and subjective (relevance of teaching to a learner, cognitive interests of a learner, nature of cognitive activity, personal experience, attitude to separate components of teaching process, etc). It is undoubted that the success of education and development is mainly conditioned by subjective factors, namely, by how personally significant and motivating learning and teaching is to learners, what is their attitude to teaching goals, style of organisation and results as well as to classmates and teachers including organisers, advisors and consultants of this process.

2. To foresee education goals that respond to peculiarities of learners' values internalisation level, to develop a system of goals meeting those peculiarities, to integrate them into goals of a particular lesson or event and to renew them taking into account the achieved results. As it was revealed in the researches discussed above, upper secondary learners lack a favourable (positive) and conscious (well-founded) attitude to separate 
spiritual values, ability to deeply perceive the essence of values. They demonstrate a too weak need to strive for value-based experiences and practical implementation of values. Considering the aforesaid, common goal of education could be formulated in the following way: to enable uppers secondary learners to internalise the key spiritual values and establish adequate relations with the world based on those values. The following partial direct objectives can be derived: 1) to assist learners in formulation of positive and conscious attitude to essential spiritual values; 2) to enrich their emotional valuerelated experiences; 3 ) to evoke need and determination to realise spiritual values and especially to accumulate a positive experience of meaningful behaviour. Perceiving complexity of these goals, it would be worth establishing partial indirect goals comprising identification of certain learners' abilities, their evoking and application. They may facilitate achievement of higher level of upper secondary learners' internalisation of spiritual values and relations. It includes: a well-rounded self-cognition, adequate self-evaluation, and a purposeful management of emotions, empathy, constructive communication and skills of purposive lifestyle establishment.

3. To realise educational potential of the subject taught: to highlight the most essential values, norms and outlook-based ideas, to select teaching material that meet them, to develop a cycle of lessons for presentation of this material, etc. In such case, it is important to follow the attitude that every subject taught is a source of certain scientific knowledge and social, moral, esthetical, gnostic and religious values. The ideas of social constructivism that have been circulating lately orientate education content namely to development of general competences and principles and their application rather than to acknowledgment of knowledge importance. On the other hand, the content of values and norms is to be implemented as an organic part of learning material. As it was pointed out by American philosopher A. Gutmann, the attitude that some educators teach learners English, history, mathematics or other subjects, whereas others attend to children's souls should be rejected. However, it is important to define particularity of real possibilities in every subject. In fact, development of moral values is firstly associated with humanitarian subjects because such values and ideas function in their content directly. Nevertheless, the influence of other subjects on moral education should not be neglected either.

4. To implement educational functions of teaching methods: to be well aware of method systems (information, practical-operational, creative), their interrelation and purpose, to be able to select them and to combine traditional and non-traditional-active methods: learning through cooperation (group projects, team games, discussions, discovery methods, exercises, story making and narration, reflection, evaluation, etc). Nucci (2000), an American psychologist, states that in an academic programme it is important to identify objects that raise discussions and considerations regarding values of a particular sphere.

5. To realise an educational potential of teaching forms: to perceive and penetrate into particularity of their compatibility and application while varying structures of lessons or other events, enhancing cooperation, saving time, evoking interests, etc. educational events are frequently classified according to methods that facilitate assimilation of education content. Since demonstration, oral and activating methods usually prevail in such 
events, a system of education forms established by the education scientist L. Jovaiša considering the above mentioned is valuable from the theoretical and practical point.

6. To establish positive relations with learners, based on principles of humanism and partnership that facilitate achievement of humanistic communication style, close interaction and a good self-feeling. It is important to select criteria of objective evaluation of value orientation and behaviour and to be interested in how learners accept assignments and how the latter become of personal importance to school students, what experiences are evoked and how learners' evaluations change. In fact, it is necessary to approach the teaching process as a holistic phenomenon and to resourcefully direct its every each part to cognition, experience and application of values. In other words, the teaching process should be favourable for development of learners' values development and enhancement of humanistic relations.

7. To perceive the structure of values internalisation which consists of cognitive, emotional, volitional and behaviour components, to perceive their role and particularity of it at different age periods and also to penetrate into the content of each component, possible forms of their manifestation and criteria for evaluation of level.

Obviously, all this requires from an educator not only subject-related but also pedagogical, psychological and cultural competence as basis for pedagogical excellence. In this aspect, it is important to nurture spiritual maturity of educator's personality orientating oneself to the highest values systems that derive from beauty, truth and goodness. Penetrating into the hierarchy of the values, it is important to attach a particular role to moral values as an integral part of spiritual values system. Since moral values are considered to be values of relations and serve as basis for the existence of other values, the importance of other spiritual values should not be neglected.

\section{Role of Mathematics in Development of Values}

As it has been mentioned above, each subject taught at school cannot be neutral regarding development of values. Mathematics is not an exception. This idea is proved by mission and concrete goals of teaching mathematics provided for in the Lithuanian Programme of Mathematics $(1997,2003)$. From the point of view of the authors of the programme, mathematics is determined as a tool and means of science, technology and daily person's life, as an important source of mankind culture and an integral part of modern communication. General objectives of teaching mathematics are interrelated not only with acquisition of learners' mathematics knowledge, skills and abilities, training of thinking and development of logical culture and mathematical abilities but also with formation of learners' character and moral principles as well as education of esthetical perception of the world. Whereas Japanese, writing about employment of teaching process in moral education and searching for links of each school subject with moral education, relate teaching of mathematics with development of respect to all the live and with learning to establish and maintain appropriate relations, to obey the elder.

The factors, conditioning potential of mathematics in development of school learners' value orientations and principles, comprise the content, lesson organisation and re- 
lations. Education scientist Cibulskaite (2000), having researched application of humanism principle teaching mathematics in 5th form, pointed out the most relevant factors of humanisation of teaching mathematics: content of mathematics, methods of teaching mathematics, relations between teachers and learners or learners themselves.

Differently from contents of humanitarian or social sciences, the content of mathematics is not characterised of humanistic values functioning directly. To develop them, firstly there is a need to humanise content of mathematics, supplementing it with problems of social, cultural, moral and spiritual life, especially the ones that are related with values topical to school learners, according to the opinion of psychologists and education scientists, the history-based principle can serve the purpose when information regarding history of mathematics science ideas, theories, trends and relevant facts origin and their development are employed. The content should also include information of life and creation of separate founders of mathematics science, especially emphasising the character features that are to be developed in children, thus, providing them with natural opportunity to perceive importance of common human values.

The principle of relation between science and life plays an important role in humanising the content of mathematics. While doing that, N. Cibulskaite related the mathematical assignments with topical material that integrates sensitivity, openness, dignity, and responsibility, as the key manifestation of humanism. Other researchers (A. Ažubalis, G. Butkienè, A. Kepalaitè, T. McLaughlin, G. Ščiukina, etc) state that with the help of this principle, it is possible not only to prompt value principles of learners but also to facilitate implementation of the teaching goals. As the latest research conducted in VPU show, approximately half of learners $(49.8 \%)$ consider mathematics to be the most difficult subject.

The principle of integration (interdisciplinary and sociocultural) is of no less importance. It allows for better understanding of mathematics while learning other subjects as well as significance of these subjects while learning mathematics. Besides, mathematics provides various means for implementation of teaching goals of subjects as well as for finding solutions to real problems of life. The Guidelines for Integrated (additional) Programmes (2004) state that mathematics and civic education is interrelated through the methods applied for investigation of society phenomena, especially statistical ones and strive for a common goal to develop logic thinking; training of entrepreneurship, harmonious development and mathematics are related through possibility to discuss various practical examples that are encountered in the life of each person; links of development of cultural awareness and mathematics is expressed through emphasis of specific, mathematics-related values, norms, regulations as a part of culture as well as through application of creative mathematics, etc.

To evoke the wish of upper secondary learners to seek for internalisation of spiritual values, it is important to assist them in perception of the role of mathematics in social and moral progress of mankind. Thus, the content of mathematics should be supplemented with facts or events that highlight the relation of mathematics and morals, their interdependence, moral background of science: its service to man, truth and goodness. This would provide for an indirect evocation of positive attitude of learners towards those 
values and to foster a respect for mathematics as a value, to enhance students' interest in future progress of mathematics. Positive attitude to mathematics is a relevant precondition for outspread of educational potential of mathematics.

Similar to any other subject, the effect of mathematics on learners' moral values is determined by the teaching methods applied. On the other hand, mathematics, like any other subjects employ specific and general methods. Not getting in to analysis of the first methods, methods of group communication should be prioritised among general methods that may be employed for development of learners' value principles while teaching mathematics. The majority of researchers who theoretically and practically develop an idea of learning through cooperation, provide arguments proving that such learning method not only stimulates activity, independence of learners as relevant conditions for manifestation of creativity but also increases mutual understanding, openness, respect, mutual assistance, sharing of experience, responsibility for own actions as basis for social skills, simultaneously allowing for establishment of favourable interpersonal climate and normal relations. In fact, stimulating imagination of learners as an impulse to creativity, sensation of beauty, identification of purpose, interest, creative methods play an important role.

\section{Conclusions}

1. Globalisation, which is based on a complex idea of interlinking, influences culture as relevant sphere of purport that comprises all individual's activities. While developing extent of globalized culture and estranging it from a particular location, globalisation may presuppose alienation of relations of a person with local communities and separate individuals, what may result in an insufficient internalisation (adoption) of values supporting those relations. On the other hand, other global tendencies, such as spread of intermediary communication, an increase in emancipation of individuals and liberation form some traditional bondages, may also influence modern human relations, national and spiritual identity of an individual.

2. The piloting researches in value internalisation of upper secondary (17-18 years old) learners revealed certain changes in this sphere. Comparison of changes in cognitive level of terminal values, which occurred throughout 8 years, showed that mature love, internal harmony, wisdom, true friendship, happy family, happy life, happiness and freedom remain among the most acknowledged values. The most significant positive tendency was observed in the learners' attitude to family and equality, the most negative one occurred in that to true friendship, partially to internal harmony. Whereas, the approach to the least acknowledged values such as national security, rescue, beauty, interesting and comfortable life has a tendency to fluctuate and evaluation of creativity and social acknowledgment shows a downward trend.

3. Evaluation of responsibility prevailed among instrumental values and revealed a clear-cut upward trend. Lately positive changes have been observed in upper secondary learners' attitude to courage and lenience as well as to politeness and honour; negative 
changes have occurred in evaluation of independence, sophistication and intelligence. Moreover, evaluation of the least acknowledged values such as imagination, potential, width of viewpoints and joy at upper secondary age continued to decrease. On the other hand, upper secondary learners showed a lower perception of value meaningfulness: more often they provided hedonistic or pragmatic meaning to instrumental values compared to terminal ones.

4. Emotional level of value internalisation revealed some positive trends such as positive attitude to practical, communicative and altruistic emotions. Though the learners' attitude to gnostic and esthetical emotions rose, the goodness and science remained among the pleasures of least value. The results of behaviour level revealed that the learners of this age group were more successful in realisation of moral values: faithfulness, responsibility, honesty and sensitivity. A more frequent exercise of duties, telling the truth, manifestation of self-respect and respect to others, concern about others, devotion to work, belief were observed. Experience of beauty, openness to novelty, independence tolerance and manifestation of intelligence was obviously less frequent. Thus, practical realisation of independence, altruism, creativity and tolerance is a particularly topical pedagogical problem.

5. Though changes in values internalisation at upper secondary age may be considered only as certain fluctuations, in order to direct them positively, it is important to employ the teaching process appropriately. Firstly, it is necessary to penetrate into factors that determine educational efficiency of the teaching process such as aims, content, methods, forms, relations, personality maturity of an educator. Secondly, it is important to follow the principle that all the subjects possess real potential. Thirdly, is essential to penetrate into specific possibilities of each subject, including mathematics.

6. Enhancing the role of mathematics in development of learners' values, it is necessary to base humanisation of the content of mathematics on the principles of history and integration, to supplement it with actual problems of science and life, including separate spiritual values such as gnostic, moral, social, esthetical and religious in to the sphere of influence of mathematics. Simultaneously, it is important to employ active teaching methods, to nurture harmonious relations of teachers and learners and to form a positive attitude to mathematics.

\section{References}

Andrijauskas A. (2000). Teorinès ir metodologinės kultūros problemos (in Lithuanian, Theoretical and methodological problems of culture). Kultūrologija, $\mathbf{6}$

Bendroji ugdymo programa ir išsilavinimo standartai (in Lithuanian, General Programme and Standards for Education). Vilnius, Švietimo aprūpinimo centras.

Džežulskis-Dienys E. (2004). Filosofija šiuolaikiškai (in Lithuanian, Philosophy in Modern Context). Kaunas, Technologija.

Cibulslaite N. (2000). Matematikos mokslo humanizavimas V-je pagrindinės mokyklos klaseje (in Lithuanian, Humanisation of science of mathematics in the 5th form of basic school). Doctor's Dissertation, Vilnius.

Giddens A. ( 2000). Modernybe ir asmens tapatumas (in Lithuanian, Modernity and Self-Identity). Vilnius, Pradai.

Integruojamuju (papildomuju) programu gairès (in Lithuanian, Guidelines for Integrated (Additional) Programmes). Vilnius, Švietimo aprūpinimo centras. 
Ivanauskienė V.( 2002). Paauglių vertybinių orientacijų reitingo ypatumai (in Lithuanian, Rating peculiarities of teenagers' value orientations). Pedagogika, 59, 25-31.

Jameson F. (1998). The Cultural Turn Vilnius. Lietuvos rašytojų sajungos leidykla.

Krukauskienė E., I. Trinkūnienė, V. Žilinskaitė (2004). Jaunimo kultūrinis identitetas: prioritetai, nuostatos, etnine kultūra (in Lithuanian, Cultural Identity of Youth: Priorities, Attitudes, Ethnic Culture). Vilnius.

Kuzmickas B. (2003). Globalizacija - priklausomybès ir tapatybès (in Lithuanian, Globalisation: Subjections and Identities). Globalizacija. Vilnius: Lietuvos teisès universitetas.

Lickona T. (1991). Educating for Character: How Our School Can Teach Respect and Responsibility. New York-Toronto-London-Sydney-Auckland Bantam bodes.

Martišauskinė E. (2004). Paauglių dvasingumas kaip pedagoginis reiškinys (in Lithuanian, Teenagers' Spirituality As a Pedagogical Phenomenon). Vilnius, Vilniaus pedagoginio universiteto leidykla.

Morkūnienė J. (2003). Taikos kultūra - naujoji globalinio mąstymo paradigma (in Lithuanian, Culture of Peace: the New Paradigm of Global Thinking). Globalizacija. Vilnius, Lietuvos teisès universitetas.

Nucci L.P. (2001). Education in the Moral Domain. Cambridge University Press.

Sheldrake P. (1992). Spirituality and History: Christian Living and the Doctrine of God. Marykmoll, New York.

Teresevičienè M., G. Gedvilienė (2000). Mokymasis bendradarbiaujant (in Lithuanian, Learning through Cooperation). Vilnius, Garnelis.

Tomlinson J. (2000). Globalisation and Culture. Polity Press in association with Blackvwell.

Thompson J. (1990). Ideology and Modern Culture. Cambridge, Polity Press.

V. Aramavičiūtè is $\mathrm{PhD}$ in social sciences, professor at Departement of Educational Science, Vilnius University. She is editor-in-chief of the journal "Acta - Peadagogica Vilnensia". Her research interest is moral education and spiritual maturity of personality, delinquant pedagogy.

\section{Vyresniuju mokiniu vertybès ir matematikos vaidmuo jas ugdant}

\section{Vanda ARAMAVIČIŪTÉ}

Straipsnyje iškeliama kultūros problema globalizacijos fone, svarstomas globalizacijos ir globalizuotos kultūros poveikis žmonių vertybėms ir santykiams, kaip jų dvasinio pasaulio išraiškai. Šiame kontekste aptariama ir tarpininkaujamojo bendravimo, vykstančio šiuolaikiniu informaciniu ir komunikacinių technologiju pagalba, itaka asmens dvasiniam tapsmui.

Remiantis tyrimo duomenimis, apibūdinami vyresniujų mokinių (17-18 m. jaunuolių) dvasiniu vertybių internalizacijos (pasisavinimo) lygmens ypatumai, užfiksuoti 1998, 2001 ir 2005 metais. Lyginamuoju aspektu analizuojama informacija apie vertybių internalizacijos kognityvinị, emocinị ir elgesio lygmenis bei jụ kaitos tendencijas.

Atsižvelgus ị konkrečius tyrimo duomenis, aktualizuojamos mokymo proceso - vieno iš svarbiausių ugdymo veiksnių galimybès internalizuojant dvasines vertybes vyresniame mokykliniame amžiuje. Pažymima, kad tam visų pirma aktualu ịsigilinti ị mokymo proceso auklejjamajị efektyvumą lemiančius veiksnius: tikslus, turinị, metodus, formas, santykius, pedagogo asmenybès dvasinę brandą. Antra, laikytis požiūrio, kad visi mokomieji dalykai turi realių auklèjamujų galimybiu, kurias būtina apibrèžti ir îsigilinti i ju specifiką.

Stiprinant matematikos, kaip reikšmingo kultūros šaltinio, vaidmenị ugdant mokiniu vertybes, pravartu daugiau pasiremti istoriškumo, ryšio su gyvenimu, dalykinès ir sociokultūrinès integracijos principais, kreipiančiais ị matematikos turinio humanizavimą, jo pildymą aktualiomis mokslo ir kultūros bei socialinio gyvenimo problemomis. Šalia to būtina aktyvinti matematikos mokymo procesą puoselèjant jame darnius mokytojų ir mokinių, pačių mokinių tarpusavio santykius, sudarant sąlygas išgyventi mokymosi sẻkmę ir susidaryti teigiamą požiūrị ị matematiką ir ị jos kūrejją žmogur. 